\title{
Perception of Professional Secretaries on Relevance of Shorthand Skills on the Modern Office Operations in Public Universities in North-East, Nigeria
}

\author{
MA'AJI E. G. ADAMU I. ISTIFANUS, M. C. \\ Department of Vocational and Technology Education, Faculty of Technology Education \\ Abubakar Tafawa Balewa University Bauchi, Nigeria
}

\begin{abstract}
The study assessed the Perception of Professional Secretaries on Relevance of Shorthand Skills on The Modern Office Operations in Public Universities in North-East, Nigeria. The study was guided by 6 objectives, 6 research questions and 6 hypotheses. Survey design was adopted for the study. The population for this study comprised of the entire 203 trained professional secretaries in public universities in North-East, Nigeria. The Total Population Sample (TPS) of 203 secretaries were used for the study. The instrument used for data collection was questionnaire adapted from Sarki (2015), Oguntimehin and Oludele (2017). The instrument was validated by experts and pilot tested and a reliability co-efficient of 0.83 was obtained. The researcher assisted by 5 co-opted research assistants administered the questionnaire using on-the-spot technique. The data to be collected were analyzed using mean and grand mean to answer the research questions while Analysis of Variance (ANOVA) was used to test the null hypotheses at .05 confidence level of significance. The result revealed among others that Shorthand skill is not relevant on report writing minute-taking of secretaries in modern offices operation. It was concluded that the job opportunities and job performance of professional secretaries will depend on their knowledge, skills and competencies on the operation of the technology gadgets and facilities found in the modern offices. Based on this, it was recommended among others that Modern technology such as (computer, scanning machine, tape recorder, dictating machine) should be integrated into the curriculum of business education programme, this will enable preservice secretaries to acquire skills needed for office operation before graduation.
\end{abstract}

Keywords: Professional, Secretaries, Shorthand, Skills, Modern, Office, Operations

DOI: $10.7176 /$ RHSS/10-2-05

Publication date: January $31^{\text {st }} 2020$

\section{INTRODUCTION}

Secretaries otherwise known as administrative assistants are employed personnel responsible for performing a wide range of jobs that vary greatly in an organisation. According to Amoor and Magaji (2015), secretaries are responsible for managing records and information, answer telephones calls, handle correspondence, schedule appointments, make travel arrangements, and sort mail in an organisation. The authors stressed that the ancient secretaries were then more or less stereotyped as the person in the office who types, files correspondence, takes of minutes and correspondence with speed and accuracy. This therefore means that the task of secretaries in an organisation is great, enormous and time consuming; hence the need to develop methods of taking abbreviated notes so that they could capture as much as possible of their employers' words at reasonable time become very important. To enable the secretaries meet up with the work challenges, sufficient speed and accuracy, the modern precursor of the shorthand was developed in $16^{\text {th }}$ Century (Amoor, 2014). This explained why Sholagbade (2012) maintained that the competency of a secretary was then hinged on her ability to take shorthand notes as dictated by the executive and transcribed same accurately. By implication, excellent knowledge, understanding and demonstration of shorthand skills guaranteed job as professional secretary in an organization.

Shorthand also called stenography is one of the core subjects to all students that opted for secretarial studies in tertiary institutions in Nigeria. The Pitman shorthand new course, new Era Edition (1979) defines shorthand as a way of representing every sound heard in English words with signs and symbols. Osuala (2004) highlighted that the primary objectives of shorthand is to develop in the students the ability to take dictation with sufficient speed and accuracy to produce amiable transcript. According to Amoor and Magaji (2015), the knowledge of Shorthand aids in the development of skills related to listening, focus, organization, attention to detail and accuracy. Okoro (2017) opined that the knowledge of shorthand enhances vocabulary, reading, phonetics, spelling and other language skills. It is assumed that knowledge and skills in short hand enable secretaries to become proficient in their duties, increase their writing skills, facilitate the taking of minutes and transcription of the spoken word. Consequently, shorthand was allocated three credit units in every semester in the curriculum of students opting for office option in tertiary institutions in Nigeria.

In the recent, the invention of technology such as Computers, fax machines, electronic mail, copy machines, scanners and some technological advancement into offices leads to several changes in both private and public offices as regards the functions of secretaries. Consequently, Oludele (2008) reported that the nature of office 
works and the office today is being largely automated with modern technologies. Sholagbade (2012) opines that technologies, such as speed typing and voice recognition software have taken the place of the former administrative art known as Shorthand. Empirically, the study of Aliata and Hawa, (2014) revealed that the emergence of technological innovations in office has created an impression that many secretaries will be relieved of their jobs since automation is likely to take over their jobs. As a result of the growing trend, the role of secretaries in the business set up has changed tremendously from that of typewriting, shorthand dictation, answering of telephone calls and processing of mails to the usage of computers and other modern gadgets (Mumuni \& Sam 2014). The aspects of the job and responsibilities such as making travel arrangements, scheduling conferences, and transmitting staff instructions are now conducted outline. The technological innovations in the offices as resulted in the deemphasizing of shorthand led to the integration of technological innovations into curriculum of secretarial programme in tertiary institutions in Nigeria (Oguntimehin \& Oludele, 2017). Therefore, there is no gain saying that technological changes have altered the procedures and techniques for office functions to include the computers, electronic mail, voice mail, and the internet.

Despite the role of technological advances made in recent years with dictation equipment and other substitutes for manual shorthand, the idea on deemphasizing on shorthand is not accepted by scholars of business education and office technology in Nigeria. Nwosu (2003) reported that, unlike word processing operations in most settings, office Secretaries carry out tasks which often extend beyond typing or keyboarding. The author added that, shorthand skill plays a vital role when a secretary work and prepares documents needed with urgently. Accordingly, Agboola, Ademiluyi and Ademiluyi (2014) reported that despite the technological age, shorthand assist secretaries to compile minutes, prepare reports and office management. Similarly, Amoor (2014) reported that secretaries with shorthand skills are more efficient in handling of paperwork and correspondence in an office. Earlier, Okoji (2008) argued that a person cannot be a secretary without attaining acceptance level of proficiency to the core subjects of secretarial training in shorthand among others. In Nigeria, among the skills required of a secretary, much emphasis is often laid on shorthand. This can be testified by the numerous newspaper advertisements for the post of secretaries demanding various speeds in shorthand. It is surprise that professional secretaries and scholars are still emphasizing shorthand skills despite the technological innovations in the modern offices. To this end, the researcher sought to assess the relevant of shorthand on job performance of secretaries in the automated offices.

In the past, Shorthand enjoyed a pride of place in secretarial profession. Knowledge and competency in the subject was considered very vital on office work of secretaries due to inherent benefits of facilitating dictation, production of amiable transcript with sufficient speed and accuracy. Today, technology is taking the world by surprise. By this, modern office machines and equipment such as computer, word processors, Tape Recorders, Dictating machines among others are being produced. According to Oludele (2008), technological innovation is changing the nature of office works and the office today is being largely automated with modern technologies. Sholagbade (2012) opines that technologies, such as speed typing and voice recognition software are taking the place of the former administrative art known as Shorthand. Earlier, Anyakoha (2002) and Akpomi (2003) opined that automated equipment have more convenience in office service delivery than Shorthand. As a result of these innovations, Adebusi (2001) recommended that the National Board for Technical Education (NBTE) should urgently reconsider de-emphasizing Shorthand and introducing full computer studies in Secretarial Education.

Despite the technological revolution in offices, the Association of Professional Secretaries in Nigeria insists that Shorthand is an anchor that every professional secretary must possess. High proficiency in Shorthand skill remains "indispensable criterion for selection and promotion of professional secretaries in most organizations in Nigeria. Amoor and Magaji (2015) reported that Shorthand is still relevant in the office operation of secretaries. The author stressed that no technology has completely render Shorthand obsolete. The arguments among scholars urge the researcher to undergo a study on the continued relevance of Shorthand in today's modern office operations of secretaries. The specific objectives of the study is to assess the perception of secretaries on: (1) the relevance of shorthand skills on report writing in modern offices operation; (2) the relevance of shorthand skills on minutetaking in modern offices operation; (3) the relevance of shorthand skills on recording instructions in modern offices operation; (4) the relevance of shorthand skills on taking down telephone calls in modern offices operation; (5) the relevance of Shorthand skills on mails and information processing function of Secretaries in modern offices operation; and (6) the relevance of Shorthand skill on time management in modern offices operation.

\section{Research Questions}

In line with the specific objectives, the following research questions were raised:-

1. What is the perception of Secretaries on the relevance of shorthand skills on report writing in modern offices operation in North-East, Nigeria?

2. What is the perception of Secretaries on the relevance of shorthand skills on minute-taking in modern offices operation in North-East, Nigeria?

3. What is the perception of Secretaries on the relevance of shorthand skills on recording instructions in modern offices operation in North-East, Nigeria? 
4. What is the perception of Secretaries on the relevance of shorthand skills on taking down telephone calls in modern offices operation in North-East, Nigeria?

5. What is Ascertain the relevance of Shorthand skills on mails and information processing function of Secretaries in modern offices operation in North-East, Nigeria?

6. What is the relevance of Shorthand skill on Secretaries time management in modern offices operation in North-East, Nigeria?

\section{Research Hypotheses}

In line with the specific objectives, the following research questions were raised:

HO1 There is no significant difference among the mean responses of secretaries' based on their working experience on the relevance of shorthand skills on report writing in modern offices operation in NorthEast, Nigeria.

$\mathbf{H O}_{2}$ There is no significant difference among the mean responses of secretaries' based on their working experience on the relevance of shorthand skills on minute-taking in modern offices operation in NorthEast, Nigeria.

HO 3 There is no significant difference among the mean responses of secretaries' based on their working experience on the relevance of shorthand skills on recording instructions in modern offices operation in North-East, Nigeria.

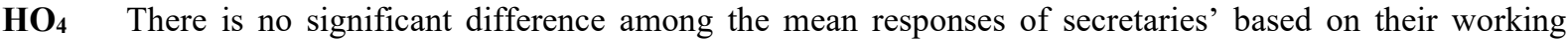
experience on the relevance of shorthand skills on taking down telephone calls in modern offices operation in North-East, Nigeria.

HO5 There is no significant difference among the mean responses of secretaries' based on their working experience on the relevance of Shorthand skills on mails and information processing function of Secretaries in modern offices operation in North-East, Nigeria

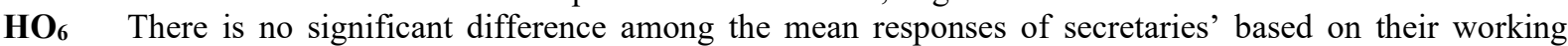
experience on the relevance of shorthand skills on time management in modern offices operation in NorthEast, Nigeria.

\section{Conceptual Framework}

The study is built on six cardinal functions of shorthand on the job performance of secretary in an office stipulated by Adam (2015) and Ejeka (2017). According to scholars, a shorthand skill improves the efficiency, credibility, accuracy, effectiveness, time management and job performance of secretaries. Amoor (2014) augured that shorthand skills is relevant to secretaries in report writing, minute taking, recording of instruction, writing down telephone messages, processing information and time management of secretaries. The major relevant of shorthand according to the framework is as presented in figure 1.

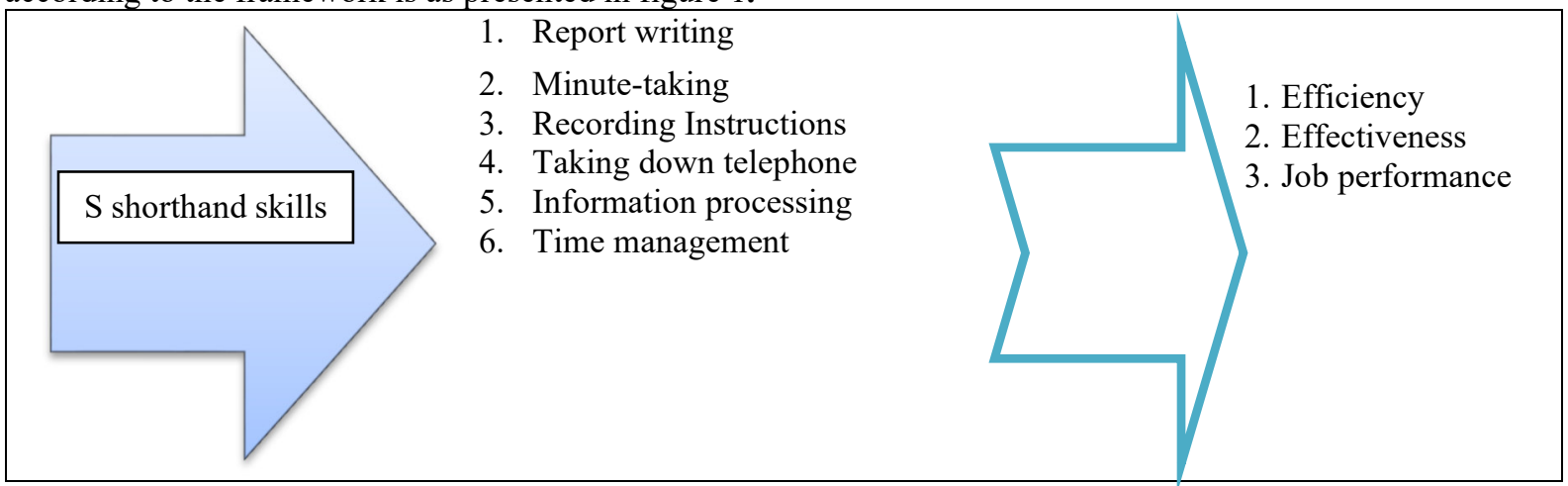

Figure 1: Conceptual framework on relevance of Shorthand skills on secretary's job performance

The proponents of the conceptual framework such as Whitehead (1977) maintained that the qualities required by the graduate office secretary include among others a wide range of shorthand skills of 100-120 wpm. The skills accounting to the author assist secretaries in area of spelling, sound knowledge of reprography, report writing and minute taking. Agboola, Ademiluyi and Ademiluyi (2014) maintained that pre-service secretaries must be proficient in typing and shorthand. The critics of this model maintained that with the advancement of technology and its role in the present day offices, secretaries are expected to be up to date in word processing, spreadsheets, PowerPoint presentations, database management and elementary accounting packages. The critic of the model maintained technology has silence the importance of shorthand in an office. Ejeka (2017) argued that at technological era, the millennium secretaries must be adept on the computer in word processing, spreadsheets, CorelDraw, and desktop publishing. Based on the trend of the argument, the conceptual framework was used to elicit information from professional secretaries on the relevant of shorthand on their office operation in an 
automated office.

\section{Methodology \\ Research Design}

The design used in this study was descriptive survey. Survey research design according to Amoor (2014) is concerned with the collection of data for the purpose of describing and interpreting existing conditions, prevailing practices, beliefs and attitudes. The design is one of the most convenient ways to obtain facts and figures needed for a study in which the results of the analyses will be used for decision- taking and generalization. The use of the survey design is based on the advice of Jubrin (2011) who stated that, when a study involves a population or a sample of respondents from whom information is obtained either verbally or through questionnaire, the ideal design method to be adopted is the survey design. This design was considered appropriate for this study because it allowed the researcher to collect data from respondents and subject it statistical analysis.

\section{Population and Sample of the Study}

The population for this study comprised of the entire 203 professional secretaries who had Shorthand skills in public universities in North-East, Nigeria. The population was drawn from establish office in the public universities in North-East, Nigeria. Due to manageable size of the population, the researcher adopted Total Population Sample (TPS) for the study. Total population sample is the sample whereby the entire population will be used for the study (Crossman, 2018). Total population sampling a researcher chooses to examine the entire population that has one or more shared characteristics. The decision is based on recommendation of Glenn (2009) recommended that at Precision level of $\pm 3 \%$, if the sample is $\leq 1,000$, Total Population Sample should be used for the study as seen in Appendix IV. Based on this submission, the entire population of 203 professional secretaries in an automated office was used for the study.

\section{Instrument for Data Collection}

The instrument used for data collection was structured questionnaire adapted questionnaire from Sarki (2015), Oguntimehin and Oludele (2017). The instrument titled Shorthand Relevance in Office Operations (SROO) contains sections A and B. Section A elicits the working experience of the respondents. Section B contains 53 items used to gather data that answered the research questions and test the null hypotheses. The items were constructed in a four (4) rating scale of Strongly agree (SA) 4 points, Agree (A) 3 points, Disagree (D) 2 points and Strongly disagree (SD) 1 point. Respondents were required to indicate their relative agreement with each item based on the scale.

To ensure that the instrument meets the expected standard, consultations were made with 2 experts in business education and 2 in Office Management and Secretarial Studies who vetted the instrument and considered it suitable for the study. A pilot study was conducted using 40 secretaries, data collected from the pilot study was subjected to statistical analysis using the Statistical Package for the Social Sciences (SPSS) software version 21. The software was used to run Cronbach's Alpha, a reliability coefficient. The computation gave a correlationcoefficient of 0.83 .

\section{Method of Data Collection}

The instrument were distributed to respondents by the researcher assisted by 5 co-opted research assistants. Onthe-spot technique was employed in the distribution of the questionnaire. In this technique, the instrument was administered to the respondents and 2 hours was given for collection. This method reduced high frequency of missing or unreturned questionnaire. The exercise lasted for five weeks. The questionnaire retuned stood at 180 $(88.67)$

\section{Method of Data Analysis}

The data collected were analyzed in two stages. In the first stage, mean score and grand mean was used to answer the research questions. In answering the research questions, strongly agree and agree were classified as agree. A minimum mean score of 2.5 was used as benchmark for agree. Similarly, disagree and strongly disagree were classified as disagree and a mean score of less than 2.5 was considered as an index score for disagree.

Analysis of Variance (ANOVA) was used to test the null hypotheses. The choice of this tool is based on suggestion of Jibrin (2011) who opines that the use of ANOVA allows researcher(s) to test whether there is significant difference among three groups or more. In the analysis, where $P \geq \alpha$, the null hypothesis was rejected and on the other hand where $P \leq \alpha$, the null hypothesis was retained. All hypotheses were tested at .05 confidence level of significance. 


\section{Results of Research Questions}

Research Question One

What is the perception of Secretaries on the relevance of shorthand skills on report writing in modern offices operation in North-East, Nigeria?

The analysis of the 10 questionnaire items used to answer research question one presented in Table 1 revealed mean scores ranging between 2.83 to 2.06 . The grand mean of obtained was less than the index score for agree $(2.43<2.50)$ suggested that respondents disagree that Shorthand skills is relevant on Secretaries report writing in modern offices operation in North-east, Nigeria .

Table 1: Mean Response on the Relevance of Shorthand Skills on Secretaries Report Writing in Modern Offices Operation

\begin{tabular}{|c|c|c|c|c|}
\hline QI & Statement & Mean & Std. Dev & Remark \\
\hline 1. & Shorthand skills are helpful in taking minutes of meetings accurately. & 2.32 & 0.72 & DA \\
\hline 2. & $\begin{array}{l}\text { Shorthand skills help the secretaries to accurately follow the steps } \\
\text { involves in taking minutes of meetings. }\end{array}$ & 2.42 & 0.81 & DA \\
\hline 3. & $\begin{array}{l}\text { Shorthand skills enable secretaries to achieve a greater accuracy and } \\
\text { fluency in meetings }\end{array}$ & 2.52 & 0.87 & DA \\
\hline 4. & $\begin{array}{l}\text { Shorthand skill is important to accurately translate outlines into full } \\
\text { notes quickly after a meeting }\end{array}$ & 2.46 & 0.83 & DA \\
\hline 5. & $\begin{array}{l}\text { Shorthand skill enables secretaries to accurately write clear sentences } \\
\text { and paragraphs in minutes of meetings }\end{array}$ & 2.57 & 0.94 & A \\
\hline & Secretaries do not require Shorthand skills to help them take minutes & & & \\
\hline 6. & $\begin{array}{l}\text { of meetings accurately } \\
\text { Shorthand skills helps secretaries to accurately summarized minutes }\end{array}$ & 2.43 & 0.83 & DA \\
\hline 7. & of meetings in an organization & 2.43 & 0.80 & DA \\
\hline 8. & $\begin{array}{l}\text { Shorthand skills helps secretaries to speedily follow the steps } \\
\text { involves in taking of meetings }\end{array}$ & 2.38 & 0.77 & DA \\
\hline 9. & $\begin{array}{l}\text { Shorthand skills helps secretaries to speedily take information when } \\
\text { taking minutes of meetings }\end{array}$ & 2.29 & 0.69 & DA \\
\hline 10. & $\begin{array}{l}\text { Secretaries use Shorthand skills to speedily display their professional } \\
\text { image in taking minutes of meetings }\end{array}$ & 2.46 & 0.83 & DA \\
\hline & Grand mean & 2.43 & & DA \\
\hline
\end{tabular}

Source: Fieldwork, 2019

\section{Research Question Two}

What is the perception of Secretaries on the relevance of shorthand skills on minute-taking in modern offices operation in North-East, Nigeria?

The analysis of the data used to answer research question two in Table 2 revealed the mean scores ranging between 2.63 and 2.33. The cumulative grand mean score of 2.46 obtained was less than the 2.50 index score for agreed. The result therefore suggested that secretaries disagree with relevant of Shorthand skills on minute-taking in modern offices operation in North-east, Nigeria.

Table 2: Mean Response on the Relevance of Shorthand Skills on Secretaries Minute-taking in Modern Offices Operation

\begin{tabular}{|c|c|c|c|c|}
\hline QI & Statement & Mean & Std. Dev & Remark \\
\hline 11. & $\begin{array}{l}\text { Shorthand skills is relevance to secretaries' accuracy in minutes } \\
\text { taking in automated office }\end{array}$ & 2.41 & 0.71 & DA \\
\hline 12. & $\begin{array}{l}\text { Shorthand skills is relevant to secretaries' writing instruction from } \\
\text { telephone call }\end{array}$ & 2.45 & 0.97 & DA \\
\hline 13. & $\begin{array}{l}\text { Shorthand skills is not relevant to secretaries' ability to compose } \\
\text { correspondence in automated office }\end{array}$ & 2.47 & 0.71 & DA \\
\hline 14. & $\begin{array}{l}\text { Shorthand skills is very relevant to secretaries' ability to write } \\
\text { instruction from his superior officer }\end{array}$ & 2.50 & 0.95 & A \\
\hline 15. & $\begin{array}{l}\text { Shorthand skills is relevant to report writing ability of secretaries in } \\
\text { automated office }\end{array}$ & 2.48 & 0.76 & DA \\
\hline 16. & $\begin{array}{l}\text { Shorthand skills is relevant to secretaries' recording confidential } \\
\text { information in the office }\end{array}$ & 2.47 & 0.81 & DA \\
\hline \multicolumn{2}{|c|}{ Grand mean } & 2.46 & & DA \\
\hline
\end{tabular}

Source: Fieldwork, 2019 


\section{Research Question Three}

What is the perception of Secretaries on the relevance of shorthand skills on recording instructions in modern offices operation in North-East, Nigeria?

The result in Table 3 used to answer research question three revealed the grand mean scores of 2.43 which was found to be less than the 2.50 benchmark for agreed. The result therefore suggested that secretaries disagree on the relevance of shorthand skills on recording instructions in modern offices operation in North-East, Nigeria

Table 3: Mean Response on the Relevance of Shorthand Skills on Secretaries Recording Instructions in Modern Offices Operation

\begin{tabular}{|c|c|c|c|c|}
\hline $\begin{array}{l}\text { Q } \\
\mathrm{I}\end{array}$ & Statement & Mean & $\begin{array}{l}\text { Std. } \\
\text { Dev }\end{array}$ & $\begin{array}{l}\text { Re } \\
\text { mar } \\
\text { k } \\
\end{array}$ \\
\hline 17. & Shorthand skills helps secretaries to take telephone messages to save callers' time & 2.42 & 0.82 & DA \\
\hline 18. & $\begin{array}{l}\text { Shorthand skills help secretaries to take telephone messages to serve as backup for } \\
\text { unto recording facility. }\end{array}$ & 2.46 & 0.83 & DA \\
\hline 19. & Shorthand skills help secretaries keep confidential telephone messages. & 2.54 & 0.88 & A \\
\hline 20. & Shorthand skills help secretaries record oral discourse over telephone lines. & 2.37 & 0.75 & DA \\
\hline & $\begin{array}{l}\text { Shorthand skills help secretaries taking lengthy verbal instructions from the } \\
\text { executive over telephone line. }\end{array}$ & 2.40 & 0.80 & DA \\
\hline 22 . & Shorthand skills helps secretaries with the ability necessary in communication & 2.40 & 0.82 & A \\
\hline 23. & $\begin{array}{l}\text { Shorthand skills help secretaries to communicate effectively with others using the } \\
\text { range of spoken, written, and other non-verbal means of expression }\end{array}$ & 2.40 & 0.81 & DA \\
\hline 24. & Shorthand skills helps secretaries to communicate clearly & 2.54 & 0.84 & DA \\
\hline 25. & $\begin{array}{l}\text { Shorthand skills have no relevance to secretaries ability to interact effectively in } \\
\text { the office }\end{array}$ & 2.46 & 0.87 & \\
\hline 26. & Shorthand skills helps secretaries while communicating ideas and information & 2.41 & 0.78 & \\
\hline 27. & $\begin{array}{l}\text { Shorthand skills help secretaries to interact effectively with other people both one- } \\
\text { to-one basis and in group }\end{array}$ & 2.40 & 0.76 & \\
\hline 28. & $\begin{array}{l}\text { Shorthand skills are not relevant to secretaries ability to evaluate information and } \\
\text { communicate effectively in the office }\end{array}$ & 2.32 & 0.73 & \\
\hline 29. & $\begin{array}{l}\text { Shorthand skills helps to secretaries to persuade groups so as to achieve desired } \\
\text { results }\end{array}$ & 2.41 & 0.78 & \\
\hline 30. & $\begin{array}{l}\text { Shorthand skills enable Secretaries to have good command of English language } \\
\text { and writing skills }\end{array}$ & 2.54 & 0.84 & \\
\hline & Grand mean & 2.43 & & DA \\
\hline
\end{tabular}

Source: Fieldwork, 2019

\section{Research Question Four}

What is the perception of Secretaries on the relevance of shorthand skills on taking down telephone calls in modern offices operation in North-East, Nigeria?

The result in Table 4 used to answer research question four revealed the grand mean scores of 2.45 which was found to be less than the 2.50 benchmark for agreed. The grand mean obtained revealed that secretaries disagree with the relevance of Shorthand skills on taking down telephone calls in modern offices operation. 
Table 4: Mean Response on the Relevance of Shorthand Skills on Secretaries Taking down telephone calls in Modern Offices Operation

\begin{tabular}{llrrl}
\hline Q! & Statement & Mean & Std. Dev & Remark \\
\hline 31. & $\begin{array}{l}\text { Shorthand skills helps secretaries in taking down lengthy verbal } \\
\text { instructions accurately }\end{array}$ & $\mathbf{2 . 4 4}$ & 0.82 & DA \\
32. & $\begin{array}{l}\text { Shorthand skills helps secretaries in saving time for handwritten } \\
\text { drafts and manuscripts compared to other usable devices }\end{array}$ & $\mathbf{2 . 5 4}$ & 0.84 & DA \\
33. & $\begin{array}{l}\text { Shorthand skills helps secretaries in taking down oral information via } \\
\text { the telephone as backup for auto-recording facility }\end{array}$ & $\mathbf{2 . 4 5}$ & 0.82 & A \\
34. $\begin{array}{l}\text { Shorthand skills helps secretaries in recording confidential } \\
\text { information }\end{array}$ & $\mathbf{2 . 4 4}$ & 0.82 & DA \\
35. & $\begin{array}{l}\text { Shorthand skills helps secretaries for error-free information/word } \\
\text { processing functions }\end{array}$ & $\mathbf{2 . 4 6}$ & 0.80 & DA \\
36. $\begin{array}{l}\text { Shorthand skills helps secretaries in production and presentation of } \\
\text { documents in standard formats in spite of the availability of } \\
\text { computer voice recognition software }\end{array}$ & $\mathbf{2 . 4 0}$ & 0.77 & A \\
37. $\begin{array}{l}\text { Shorthand skills helps secretaries for effectiveness and accuracy of } \\
\text { electronic mail processing }\end{array}$ & $\mathbf{2 . 4 0}$ & 0.81 & DA \\
$\begin{array}{l}\text { Shorthand skills helps secretaries for production of error-free } \\
\text { correspondence in spite of availability of computer spell and } \\
\text { grammar check }\end{array}$ & $\mathbf{2 . 4 3}$ & 0.84 & DA \\
Grand mean & $\mathbf{2 . 4 5}$ & DA \\
\hline
\end{tabular}

Source: Fieldwork, 2019

\section{Research Question Five}

What is the perception of Secretaries on the relevance of shorthand skills on mails and information processing functions in modern offices operation in North-East, Nigeria?

The analysis of the items used to answer research question five revealed the grand mean scores of 2.46 which was found to be less than index score of 2.5 for agree. The result revealed that Secretaries disagree with the relevance of Shorthand skills on mails and information processing function in modern offices operation in Northeast, Nigeria.

Table 5: Mean Response on the Relevance of Shorthand Skills on Secretaries Mails and Information Processing in Modern Offices Operation

\begin{tabular}{|c|c|c|c|c|}
\hline $\begin{array}{l}\text { Q } \\
!\end{array}$ & Statement & $\begin{array}{l}\text { Me } \\
\text { an }\end{array}$ & $\begin{array}{l}\text { Std. } \\
\text { Dev }\end{array}$ & $\begin{array}{l}\text { Rema } \\
\text { rk }\end{array}$ \\
\hline 39. & $\begin{array}{l}\text { Shorthand skills helps secretaries enable secretaries to meet up with urgent work } \\
\text { demand }\end{array}$ & 2.39 & 0.81 & DA \\
\hline 40. & Through Shorthand skills secretaries accomplish his task in good time & 2.50 & 0.84 & DA \\
\hline 41. & Transcribing Shorthand outlines is time consuming in office work & 2.47 & 0.86 & A \\
\hline 42. & Shorthand skills enable secretaries to take minute of the meeting in good time & 2.39 & 0.72 & DA \\
\hline 43. & Shorthand skills help in facilitating office work of secretaries & 2.55 & 0.92 & DA \\
\hline 44. & $\begin{array}{l}\text { Secretaries with Shorthand skills is fasting in report writing compare to their } \\
\text { counterparts that have not }\end{array}$ & 2.51 & 0.82 & A \\
\hline 45. & Proficiency in Shorthand assist secretaries to accomplish his task when due & 2.40 & 0.76 & DA \\
\hline 46. & Shorthand skills is not relevant to secretaries in recording of investigations & 2.46 & & DA \\
\hline & Grand mean & 2.46 & & DA \\
\hline
\end{tabular}

Source: Fieldwork, 2019

\section{Research Question Six}

What is the relevance of Shorthand skills on Secretaries time management in modern offices operation in NorthEast, Nigeria?

The grand mean of the 2.43 obtained was less that the 2.50 benchmark for agree indicated that the secretaries disagree with the relevance of Shorthand skills on time management in modern offices operation in North-east, Nigeria. 
Table 6: Mean Response on the Relevance of Shorthand Skills on Secretaries Time Management in Modern Offices Operation

\begin{tabular}{llccc}
\hline Q! & Statement & Mean & Std. Dev & Remark \\
\hline 47. & $\begin{array}{l}\text { Shorthand skills helps secretaries to write stamen of subjects in } \\
\text { investigations }\end{array}$ & $\mathbf{2 . 2 9}$ & 0.81 & DA \\
48. $\quad \begin{array}{l}\text { Shorthand skills helps secretaries in to write terms of reference of } \\
\text { an investigations }\end{array}$ & $\mathbf{2 . 3 1}$ & 0.81 & DA \\
49. $\quad \begin{array}{l}\text { Shorthand skills enable secretaries to write description of how } \\
\text { information are obtained in an investigations }\end{array}$ & $\mathbf{2 . 6 6}$ & 0.92 & A \\
50. $\quad \begin{array}{l}\text { Shorthand skills do not help secretaries to state difficulties } \\
\text { uncounted in an investigations }\end{array}$ & $\mathbf{2 . 3 6}$ & 0.72 & DA \\
51. $\begin{array}{l}\text { Shorthand skills help secretaries to write acknowledgment of } \\
\text { assistance in an investigations }\end{array}$ & $\mathbf{2 . 3 9}$ & 0.71 & DA \\
52. Shorthand skills do not provides secretaries with confidence to \\
apply their skills in report writing in an investigations \\
$\begin{array}{l}\text { Shorthand skills helps secretaries to summarize the main part of a } \\
\text { report in an investigations }\end{array}$
\end{tabular}

Source: Fieldwork, 2019

\section{Results of Research Hypotheses}

Research Hypothesis One

There is no significant difference among the mean responses of secretaries' based on their working experience on the relevance of Shorthand skills on report writing in modern offices operation in North-east, Nigeria.

The result of test of null hypothesis one in Table 7 revealed the $F / 2, .204$ with $p=.816$. The $p$-value obtained was greater than the 0.05 level of significance. The result therefore suggested that no significant difference exist among the mean responses of the three groups of respondents on relevance of Shorthand skills on report writing in modern offices operation. The null hypothesis is therefore retained. The implication is that the three groups of the respondents shared the same opinions on the relevance of Shorthand skills on report writing in modern offices operation.

Table 7: Analysis of Variance used for Testing null Hypothesis One

\begin{tabular}{llllll}
\hline & Sum of Squares & Df & Mean Square & F & Sig. \\
\hline Between Groups & .159 & 2 & .079 & .204 & .816 \\
Within Groups & 68.836 & 177 & .389 & & \\
Total & 68.994 & 179 & & & \\
\hline
\end{tabular}

Source: Fieldwork, 2019

\section{Research Hypothesis Two}

There is no significant difference among the mean responses of secretaries' based on their working experience on the relevance of Shorthand skills on minute-taking in modern offices operation in North-east, Nigeria.

The analysis of variance used to test null hypothesis two in Table 8 revealed $F=2 / 8.574$. The $p$-value was less than the alpha value $(.000<0.05)$. The result therefore, indicated that there was significant difference among the mean response of the three groups of respondents on the relevance of Shorthand skills on minute-taking in modern offices operation in North-east, Nigeria. The Post-hoc test in Table 7B indicated the observed difference is from the respondents in groups 1 and 2. The hypothesis was therefore rejected.

Table 7A: Analysis of Variance used for testing null Hypothesis Two

\begin{tabular}{llcccc}
\hline & Sum of Squares & Df & Mean Square & F & Sig. \\
\hline Between Groups & 9.093 & & 5 & 8.574 & .000 \\
Within Groups & 93.857 & & & & \\
Total & 102.950 & & & & \\
\hline
\end{tabular}

Source: Fieldwork, 2019 
Table 7B: Turkey Post-Hoc test s of null Hypothesis Two

\begin{tabular}{lllll}
\hline (I) IV & (J) IV & Mean Difference (I-J) & Std. Error & Sig. \\
\hline \multirow{2}{*}{1.00} & 2.00 & $.45238^{*}$ & .13136 & .002 \\
& 3.00 & -.04762 & .13312 & .932 \\
2.00 & 1.00 & $-.45238^{*}$ & .13136 & .002 \\
& 3.00 & .00835 & .11126 & .997 \\
3.00 & 1.00 & -.04762 & .13312 & .932 \\
& 2.00 & .00835 & .11126 & .997 \\
\hline
\end{tabular}

Source: Fieldwork, 2019

\section{Research Hypothesis Three}

There is no significant difference among the mean responses of secretaries' based on their working experience on the relevance of Shorthand skills on recording instructions in modern offices operation in North-east, Nigeria.

The result of null hypothesis three in Table 8 shows F/2, .055 with the p-value of .947 . The obtained p-value was greater than the level of the significance $(.947>0.05)$, the result shows that there was no significant difference among the respondents on the relevance of Shorthand skills on recording instructions in modern offices operation in North-east, Nigeria . The null hypothesis was therefore retained. The implication is that the three groups of students disagree with the relevance of Shorthand skills on recording instructions in modern offices operation.

Table 8: Analysis of Variance used for testing null Hypothesis Three

\begin{tabular}{llllll}
\hline & Sum of Squares & Df & Mean Square & F & Sig. \\
\hline Between Groups & .104 & 2 & .052 & .055 & .947 \\
Within Groups & 168.096 & 177 & .950 & & \\
Total & 168.200 & 179 & & & \\
\hline
\end{tabular}

Source: Fieldwork, 2019

\section{Research Hypothesis Four}

There is no significant difference among the mean responses of secretaries' based on their working experience on the relevance of Shorthand skills on taking down telephone calls in modern offices operation in North-east, Nigeria.

Analysis of variance in Table 9 used for testing null hypothesis four revealed the $F / 2, .193$. The $p$-value of .825 obtained was greater than the 0.05 level of significance. The obtained p-value suggested that there was no significant difference among the mean responses of secretaries' based on their working experience on the relevance of Shorthand skills on taking down telephone calls in modern offices operation in North-east, Nigeria . The hypothesis was therefore retained. This result indicated that the secretaries had the same opinion that Shorthand is not relevance of Shorthand skills on taking down telephone calls in modern offices operation.

Table 9: Analysis of Variance used for Testing null Hypothesis Four

\begin{tabular}{llllll}
\hline & Sum of Squares & Df & Mean Square & F & Sig. \\
\hline Between Groups & .159 & 2 & .079 & .193 & .825 \\
Within Groups & 72.836 & 177 & .412 & & \\
Total & 72.994 & 179 & & & \\
\hline
\end{tabular}

Source: Fieldwork, 2019

\section{Research Hypothesis Five}

There is no significant difference among the mean responses of secretaries' based on their working experience on the relevance of Shorthand skills on mails and information processing function of Secretaries in modern offices operation in North-east, Nigeria

The test of null hypothesis five in Table 10 shows $\mathrm{F}=2 /, .033$ with $\mathrm{p}$-value of .968 . The $\mathrm{p}$-value was greater than the level of significance $(.968>0.05)$, the result therefore shows that no significance difference exists among the mean responses on the three group of respondents on the relevance of Shorthand skills on mails and information processing function of Secretaries in modern offices operation in North-east, Nigeria . The null hypothesis was retained. The implication is that the secretaries shared the same opinion that Shorthand is not relevance of Shorthand skills on mails and information processing function of Secretaries in modern offices operation. 
Table 10: Analysis of Variance used for Testing null Hypothesis Five

\begin{tabular}{llllll}
\hline & Sum of Squares & Df & Mean Square & F & Sig. \\
\hline Between Groups & .016 & 2 & .008 & .033 & .968 \\
Within Groups & 44.711 & 177 & .253 & & \\
Total & 44.728 & 179 & & & \\
\hline
\end{tabular}

Source: Fieldwork, 2019

\section{Research Hypothesis Six}

There is no significant difference among the mean responses of secretaries' based on their working experience on the relevance of Shorthand skills on time management in modern offices operation in North-east, Nigeria.

Analysis of variance in Table 11 used for testing null hypothesis six revealed the F/2, .011 with $p=.989$. The obtained p-value of .989 was greater than the 0.05 level of significance. The p-value obtained suggested that no significance difference exists among the mean responses of secretaries' based on their working experience on the relevance of Shorthand skills on time management in modern offices operation in North-east, Nigeria. The hypothesis was therefore retained. The result therefore shows that the three groups of respondents agree that Shorthand is not relevance of Shorthand skills on time management in modern offices operation.

Table 11: Analysis of Variance used for testing null Hypothesis Six

\begin{tabular}{llllll}
\hline & Sum of Squares & Df & Mean Square & F & Sig. \\
\hline Between Groups & .005 & & .003 & .011 & .989 \\
Within Groups & 44.795 & 7 & .253 & & \\
Total & 44.800 & 9 & & & \\
\hline
\end{tabular}

Source: Fieldwork, 2019

\section{Discussion of the Major Findings}

The result of research question one and test of corresponding null hypothesis revealed that Shorthand skill is not relevant on Secretaries report writing in modern offices operation. The result agrees with the report of Dulek and Fielden, (1999) which states that secretaries now have many technologically advanced office gadgets to ease their jobs and enhance proficiency such as computer software programmes which helps the secretary to write and edit memos, letters and report, data management programs or data bases, which help the secretary to use long list of data and spreadsheet programs which handle tables and numbers. Hensan and Means (2009) reported that, electronic organizer or dictating machine takes down speeches through a microphone that is connected to a recorder, record speeches and then reproduces it like a photograph at a higher speed than with shorthand. Contrary to the finding, the study conducted by Sunday (2005) revealed that Shorthand is indispensable to secretarial profession, since Shorthand helps Secretaries in developing their Written and Oral English. Ademiluyi (2014), while assessing the continued relevance of the secretarial profession in the age of office technology, viewed effective secretarial practitioner as one who is able to arrange meetings, compile minutes and reports. In their reports, they concluded that secretarial practitioners are still needed in the office for taking telephone messages, taking dictations, recording minutes of meetings and receiving information in different formats. Since the abbreviated system of writing i.e. shorthand, is used where accurate and immediately legible recording of spoken English is required as is still the case in the contemporary office, it was concluded that Shorthand would still be relevant in office management.

The result of research question two and test of null hypothesis two revealed that Shorthand skill is not relevant on Secretaries minute-taking in modern offices operation. The finding agrees with the study Adebayo (2000) who reported that, improvement in technology may make Shorthand less useful in automated offices. Study conducted by Kombol (2006) revealed that in most cases, electronic mail has replaced letters in the post (snail mail), faxes have outmoded telegrams, computers are more efficient than typewriters and the traditional Shorthand has been overtaken by digital system. The author added that, on the whole, ICTs are based on satellite connections as opposed to world "stranded in wires"; texts, voice or pictures are sent over a large distance in seconds. Abosede and Akintola (2015) reported that the emergence of ICT which bring about modern office equipment has transformed not only the management functions but also imparted the secretarial duties and time management. The type of machines and gadgets that were used to produce, duplicate and store information has undergone a great transformation to cope with the growing world technology, as a result, the role of secretaries in the business set up has changed tremendously from that of typewriting, Shorthand dictation, answering of telephone calls and processing of mails to the usage of computers and other modern gadgets (Mumuni \& Sam 2014). Contrary to the result, the study of Ambrose (2011) reported that Shorthand is still relevant despite the introduction of sophisticated machines in offices.

The result of research question three and test of null hypothesis three indicated that the three groups of respondents all agree that Shorthand skill is not relevant on Secretaries recording instructions in modern offices 
operation. The result of the study affirmed the earlier report of Oludele (2008) who opined that technologies have changed the nature of office works and the office today is being largely automated with modern technologies as render Shorthand outdated. The author added that daily use of Shorthand and Typewriting skills has been greatly reduced in the public sector because more managers are getting involved in word processing, resulting from office automation. The role of secretaries in business has changed tremendously from that of typewriting and Shorthand dictation, answering of telephone calls and processing of mails. Today's secretaries are exposed to office technology including the internet that make work much easier and knowledge more accessible (Edwin, 2008). Sholagbade (2012) opines that technologies, such as speed typing and voice recognition software have taken the place of the former administrative art known as Shorthand. Contrary to the result, Agboola, Ademiluyi and Ademiluyi (2014), while assessing the continued relevance of the secretarial profession in the age of office technology, viewed effective secretarial practitioner as one who is able to arrange meetings, compile minutes and reports. In their reports, they concluded that secretarial practitioners are still needed in the office for taking telephone messages, taking dictations, recording minutes of meetings and receiving information in different formats. Since the abbreviated system of writing i.e. shorthand, is used where accurate and immediately legible recording of spoken English.

The result of research question four and test of corresponding null hypothesis indicated that secretaries disagree that Shorthand skill is relevant on taking down telephone calls in modern offices operation. The result is in line with the report of Akpomi (2003) which revealed that in the era of computers and information technology which has become an enabler of greater convenience have affected the place of shorthand. The author stressed that secretaries now have many technologically advanced office gadgets to ease their jobs and enhance proficiency and productivity leading to improved access to goods and services globally. The study of Hensan and Means (2009) revealed that electronic organizer or dictating machine takes down speeches through a microphone that is connected to a recorder, record speeches and then reproduces it like a photograph at a higher speed than with shorthand. Contrary to the finding, Adebusi (2001) reported that Shorthand cuts across a wide range of professionals and formal training on Shorthand will enhance better productivity. Study conducted by Silvia, Joseph and Eunice (2011) revealed that Shorthand as imparting skills of work organization and mental alertness that are crucial in the undertaking of the multiple tasks of a secretary irrespective of whether there will be Shorthand dictation or not.

Result of research question five and test of null hypothesis five shows that the three groups of respondents disagree that Shorthand skill is relevant on mails and information processing function of Secretaries in modern offices operation. The outcome of the study is in line with the earlier study conducted Agomuo (2005) which revealed that modern office skills which allow words, sentences and paragraphs to be manipulated through the use of word processor as render Shorthand less relevant. The efficiency and effectiveness of the secretary in every business organization this days does not depend on Shorthand skills rather the availability of office technologies as well as the skills and competencies of the secretary (Okoji, 2008).According to Azuka (2009) secretarial functions which were previously done manually using Shorthand skills for mailing and recording have been mechanized or automated. Adam (2011) reported that technology which is replacing the traditional ways of data processing has provided new sources of information, new ways of collecting it, storing it, and processing it, and new methods of communicating it. The study conducted by Okoro (2017) revealed that improvement in office technology may make Shorthand less useful in modern offices; there was no empirical evidence to suggest that Shorthand skill is archaic. Today's secretaries are exposed to office technology including the internet that make work much easier and knowledge more accessible (Edwin, 2008). The author added that it is now easier to send messages by telex, electronic mails (e-mails), fax and telephones compare to the traditional method of posting. Contrary to the finding, Ogunyinka (2000) reported that Shorthand has come to stay, though seen as a vocational and not educational course. Yet it has been discovered that it has educational values.

The result of research question six and test of corresponding null hypothesis shows that all the three groups of respondents disagree with the relevant of Shorthand skill on time management of secretaries in modern offices operation in North-east, Nigeria. The finding is in line with the report of Akpomi (2003) which states that the use of Shorthand is time wastage. The author added that technological advanced office equipment enhance proficiency and productivity. An automated office, obviously, grants the secretary new roles and responsibilities and help in time management. According to Oludele (2008) technological innovations have changed the nature of office works and the office today is being largely automated with modern technologies. Daily use of Shorthand and Typewriting skills has been greatly reduced in the public sector because more managers are getting involved in word processing, resulting from office automation. Word processing software provides features for spelling and grammar check, auto-margin set and templates for various display of work. Akpomi and Ordu (2009) which states the use of Shorthand is waste of time. The author stressed that that new technological equipment has altered the procedure and technique for office functions. They mentioned electronic mail/commerce, voice mail, smart phones and internet as examples. Sholagbade (2012) opines that technologies, such as speed typing and voice recognition software have taken the place of the former administrative art known as Shorthand. 
Contrary to the finding, the study conducted by Abdul-Kahar (2015) reported that Shorthand is another skill that a secretary should possess in order to write fast and then transcribe them (typing) into plain English text for ordinary person's understanding. In fact, short hand is actually a secret writing whereby if you have never studied or learnt it you can never read or figure out what is being written or said. Oguntimehin and Oludele (2017) reported that availability of auto-recording facility does not remove the relevance of Shorthand in taking down oral information via the telephone, neither do computer voice recognition software, spell and grammar check facility displace the relevance of Typewriting skills in mail processing. Okoro (2017) suggested that in the next round of curriculum review, Shorthand should be expunged to give way to modern automated equipment. This situation led many scholars to recommend that modern office technology and information systems should be integrated into the curriculum of secretarial education as Shorthand has lost its relevance.

\section{Conclusion}

The results of the study showed that the relevant of Shorthand skills on the job performance of secretaries in the modern office has reduced as a result of availability of modern office technology. It is not farfetched to infer from the foregoing that office technology which provides the secretary with additional opportunity for automatic finetuning of concrete documents or transmission of information devoid of ambiguities has rendered Shorthand skills obsolete. It therefore means that the efficiency and effectiveness of the secretary in office operation depends on their knowledge and skills on operation of modern office technology. By implication, future secretaries without requisite skills on operation of modern office gadgets will have no place in the labour market. This will increase the number of unemployment in the country.

\section{Recommendations}

Based on the findings of the study, the following recommendations were made:

1. Professional secretaries should update their computer skills that will help them writing, editing and processing report.

2. Secretaries should go for workshop and training on how to use dictation machine, computer pen and recorders for minute-taking in modern offices operation.

3. Secretaries should be trained on the use of modern technology such as handset and tape recorder for recording instructions in office.

4. Secretaries should acquire skills on how to use mobile phone to record both oral and video calls.

5. Secretaries should update their knowledge of use of internet service to sending mails and processing information in the office operation

6. Secretaries should acquire skills for using modern technology and facilities such as computer, internet facilities, scanners and photo copier that make office operation easier, better and faster

\section{REFERENCES}

Abdul-Kahar, A. (2015). The Efficacies of Secretarial Profession by Ghana Education Service and Higher Education Institutions, Journal of Education and Practice, 6 (18), 81-113.

Abosede, S. C. \& Akintola, O. A. (2015). Information and Communication Technology Facilities' Utilization and Job Performance of Secretaries in Public and Private Universities in Ogun State, International Journal of Managerial Studies and Research (IJMSR) 3 (3), 44-52

Adam A-K., (2011), Secretarial Profession in An Ever Changing Technological World, Jayee Voice, 2 (1), 7-13

Adam A-K., (2015), Secretarial Profession in An Ever Changing Technological World, Jayee Voice, 2 (1) 7 and 10

Adebayo A.E. (2000). Pitman Shorthand, Way to Success. Business Education Journal Volume 1 (1), 40-48.

Adebusi, A. M. (2001). the Relevance of Shorthand and Typewriting in Curriculum for Higher Education. Business education journal III (4), 28-38.

Agboola, J. O., Ademiluyi, L, F., \& Ademiluyi, A.B. (2014). An assessment of the continued relevance of the secretarial profession in the age of the office technology in Nigeria. Nigerian Journal of Business Education, $1(3), 159-167$.

Agomuo, E. E. (2005). Modern office technology: issues, procedures and practice Nsukka. Nigeria: University of Nigeria Press Ltd.

Akpomi, M. E. (2003). Effects of modern office technology as perceived by secretaries. Business Education Journal, 4(1), 147-155.

Aliata, M. I. and Hawa, S. A. (2014). Modern Office Technology and the Performance of the Professional Secretary in Contemporary Organizations in Ghana. Information and Knowledge Management 3(4). 52-57. Assessed from www.iiste.org in july.2014.

Ambrose, V.S. (2011). "The relevance of Shorthand to secretaries in modern office administration". Higher National Diploma (HND) Project. Nuhu Bamalli Polytechnic Zaria. 
Amoor, S. S. (2014). Determinant of choice of office option among business education in colleges of education in Nigeria. A PhD Thesis submitted to Ahmadu Bello University, Nigeria.

Amoor. S. S. \& Magaji, Z. B. (2015). The Place of Secretarial Education in Tertiary Institutions in Kaduna State, Nigeria, for Future Office 2020, Global Journal of Science Frontier Research, 15 (2)

Anyakoha EU (2002). Welcome address at the 3rd National conference of HERAN held at Princess Alexandra Unity Hall, University of Nigeria Nsukka $14-17$ September.

Azuka, E. B. (2009). "Relevance, Suitability and Adequacy of Shorthand in the $21^{\text {st }}$ Century." Business Education Journal, 3 (2).

Crossman, A. (2018). Understanding purposive sampling: An overview of the method and its applications.

Dulek A.C. and Fielden V.C. (1999). Evolution of the Internet. Retrieved 20th December, $2018 . \quad$ from www.harcourtcollege.com/infosys/poc2e/student

Edwin AE (2008). Self-employment: An option for professional secretaries in Nigeria. J. Contemporary Bus. Edu. Res. (JOCBER) 1 (1): 25-30.

Ejeka, C. A. (2017). The Relevance of Office Technology and Management (OTM) Skills in Organizational Growth and Development, International Journal of Advanced Academic Research.

Glenn, D. L. (2009). Determining sample size. Retrieved March 23, 2018, from http:lledis.ifas.ufl.edu-

Henson, A.S. and Means, K.D. (2009). Re-engineering the secretarial profession for efficiency and effectiveness in the public sector of the Nigerian Economy. Journal NAPSSON, 9 (1) $4-11$.

Jibril, A.H. (2011). Towards improving vocational and technical education. Journal of business Educational Research and Development (JOBERD, 2 (1)

Kombol, M. (2006). An Assessment of the pattern of ICT use among Nigerian Media Practitioners: Implications for Media relations Practices in Public Relations. Public Relations Journal 14 (1), 11-27.

Mumuni, I. A. \& Sam, A. H. (2014).Modern Office Technology and the Performance of the Professional Secretary in Contemporary Organisation in Ghana. Journal of Information and Knowledge Management 3(4): $52-57$

Nwosu, A. N. (2002). "Word Processing and Electronic Office Operations Competences Currently Needed by Secretaries in Selected Business offices in Abia and Imo states," Idah: Conference Proceeding on National Association of Nigerian Secretaries.

Oguntimehin, Y. A. and Oludele, L. Y. (2017). Personnel's Perception of Continued Relevance of Shorthand and Typewriting Skills to Office Management in Osun State Owned Tertiary Institutions, Nigeria, British Journal of Education, 5(3), 60-68

Ogunyinka, A. O. (2000). Welcome to Computer Science with the Basic Programming language. Enugu: Acena Publishers.

Ohakwe, S. N. (2001). "Manual Office Skills in an Information Technological Era." Business Education Journal, $2(4)$

Okoji, A.E. (2008). "Functions of the Secretary in the Era of Information Technology." The Certified Secretary and Reporter, 11 (1)

Okoro, P. E. (2017). Appraisal of Students' Academic Performance in Shorthand in College of Education, Warri, ATBU, Journal of Science, Technology \& Education (JOSTE); 6 (2), 283-292.

Oludele, L.Y. (2008). "Integrating Information and Communication Technology in the Training of Professional Secretaries: Issues and Prospects" Educational Periscope, 2 Ife: Muyis Clean Prints.

Osuala EC (2004). Principles and methods of business and computer education. Enugu: Cheston Agency Ltd.

Sarki, R. A. (2015). Relevance of Shorthand Skills on job performance of Secretarial in Automated Offices in North East Geo-Political Zone in Nigeria, PhD thesis submitted to Ahmadu Bello University, Zaria.

Sholagbade, F.A. (2012). Analysis of Academic and Professional Competencies of Professional Secretaries in Ogun State-owned Tertiary Institutions. M.Ed Dissertation Submitted to the Department of Education Foundations and Management, Faculty of Education, Olabisi Onabanjo University, Ago-Iwoye, Ogun State.

Silvia, K. V. Joseph W. N. and Majanga, E. (2011). Influence of Teachers' and Students' Attitudes Towards Performance in Shorthand in Technical Training, Current Research Journal of Social Sciences 3(2): 59-65,

Sunday, A. S. (2005). "Secretaries and Management Positions: Constraints and Solution." Journal for the Promotion and Advancement of Secretarial Professional.

Whitehead, G. (1977) Secretarial Practice Made Simple, London: W.H. Allen and Company, 3-4 